Journal Plus Education, ISSN: 1842-077X, E-ISSN (online) 2068-1151 Vol XIX (2018), No. 1. pp. 92-102

\title{
IMPLEMENTATION OF AUGMENTED REALITY TECHNOLOGY IN NATURAL SCIENCES LEARNING OF ELEMENTARY SCHOOL TO OPTIMIZE THE STUDENTS' LEARNING RESULT
}

\author{
Ali FAKHRUDIN ${ }^{1}$, Sri YAMTINAH ${ }^{2}$, and RIYADI ${ }^{3}$ \\ Master Program of Elementary School Teacher Education, \\ Sebelas Maret University, \\ Surakarta, Indonesia \\ alifakhrudin12@gmail.com
}

\begin{abstract}
In this research, the researcher developed new innovation in natural sciences learning of elementary school by implementing augmented reality technology. The method that used in this research was research and development method based on Borg and Gall theory which consists of ten stages: 1) research and information collecting, 2) planning, 3) develop preliminary form of product, 4) preliminary field testing, 5) main product revision, 6) main field testing, 7) operational product revision, 8) operational field testing, 9) final product revision, 10) dissemination and implementation. The result of this research is learning media of natural sciences learning in elementary school by utilizing augmented reality technology. Based on the implementation of experiment, it is obtained the data that learning process using augmented reality which is developed can optimize the students' learning result.
\end{abstract}

Keywords: Augmented Reality; Learning Result; Research and Development; Natural Sciences of Elementary School; Learning Media;

\section{INTRODUCTION}

Based on the result of PISA (2009), Indonesia is on the second lowest rank from the 65 countries. There are three aspects that were researched by PISA, they are: the ability of reading, mathematics, and science. The result showed that science is on the lowest rank. This is apprehensive that aspect which is measured by PISA is including the special skill in science field that is very needed in facing the global era challenge. In this case, science learning should be revised to be better. From those reasons, it becomes challenge for sciences teachers to teach science maximally to the students. One of the efforts is revising the learning system. In education field, science learning is called as natural sciences learning. Natural science (IPA) is collection of knowledge that is arranged systematically about natural 
indication. Natural science development is not only about fact, but also scientific method and scientific attitude. It is hoped that natural science education can be tool for students to learn surrounding nature. Also, the continually prospect development can be implemented in daily life. (Depdiknas, 2008).

Based on the result of survey in Surakarta, it is showed that the score of natural science is lower than the others subjects. In conducting examination, the score of natural science is in the lowest rank compared with other subjects. On the national examination in academic year of 2013/104, the average of Indonesian Language is 8, 26, mathematics 7, 38, while natural science is 7,29 . Then, on the national examination in academic year of 2014/2015, the score of natural science has significant decreased with average 62,43 . Starting from that, it is a challenge for teachers to be able to convey the science lessons as much as possible to the students. One effort that can be done to maximize learning outcomes is by improvements in the learning system.

Learning outcomes of students are influenced by internal factors and external factors. Internal factors including the students' interest and willingness in managing the material received. External factors include the availability of media and the presence of a teacher in the learning process. Learning is a process of interaction between students and teachers, both in the classroom and outside of classroom by using learning source and learning media.

Learning resources can be obtained from teachers, books, or printed media and other audio media that are expected to gain a wider knowledge. Progress in education will not happen without improving the learning process used. In other words, the quality of education is strongly influenced by the quality of learning. Therefore, the lessons to be implemented should be adjusted to the mandate of Government Regulation No. 19 of 2005 on National Education Standards, one of the standards to be developed is the process standard.

Then, to obtain good results in the learning process, it should be supported by the appropriate media that, because the learning media is an intermediary or the introduction of good communication and fun between teachers with students. The students' spirit will arise when the atmosphere is so fun and learning will be effective when they are happy in learning. Teachers' ability in designing and implementing learning media is the key to the success of fun learning process.

Grouping Learning media are very diverse, Seel and Glasgow (1990: 181-183) classify the media into two broad categories: traditional media and latest technology media. Learning media with modern technology usually involves emerging technologies such as cassette playback, video, recordings. While traditional media can be created manually by the teacher or containing 
classic elements by using materials and tools that are easily found in the environment. Teachers must be creative to create learning media in order to make learning condition which is educative, effective, and optimally efficient.

In this global era, the main multimedia is in form of ICT (Information Technology and communication) becomes a fundamental requirement in determining the quality and effectiveness of the learning process. According to Alhamuddin (2010) the process of learning using multimedia makes the learning is more deeply and fun, while for teachers the utilization of media is easier and very helpful in the process of effective learning. From Dryden and Vios (2003) study, it can be concluded from the results of their research that in successful education, self-image was more important than the learning materials. Thus, the concept of future education is directed to how to excite learners to learn in a fun way.

Nowadays, one of the trending technologies is Augemented Reality. Suryawinata (2010) stated that Augmented Reality is combination between virtual and reality world made by computer. The virtual object can be text, animation, 3D model or video that gathered with the real environment, so that the users can feel the virtual object is in their environment. Augmented Reality belongs to new technology branch. However, the development is fast. So far, this technology is used in various fields, especially in military and advertisement. And now, it started applying in education field. Elango (2015) in his research showed positive result in implementing Augmented Reality on mathematics learning. Then, Chiang, Yang \& Hwang (2015) stated that there is increasing of students' understanding in learning science through media based Augmented Reality. Also, research by Kucuk, Zilmas, and Goltas (2015) showed positive result in utilization of Augmented Reality in learning language.

In short, object can be seen more real through Augmented Reality. Therefore, it is very interesting if it is applied in learning process, especially in natural science, for it has many topics that can be learned through picture or visual. Besides, Augmented Reality can be accessed via OS Android in phone facility.

Therefore, in this research, the researcher developed new innovation in natural science learning in elementary school. It is hoped that the problems above can be solved. The researcher developed assignment worksheet that utilize technology by using Augmented Reality system and can be accessed via android. 
Journal Plus Education, ISSN: 1842-077X, E-ISSN (online) 2068-1151 Vol XIX (2018), No. 1. pp. 92-102

\section{RESEARCH METHODOLOGY}

Research design that was conducted is Research and Development (RD) that developing assignment worksheet of Natural science in elementary school based multimedia android using Augmented Reality. The development that conducted is using procedural model that adapting Borg and Gall model development.

The development according to Borg and Gall (1983) consists of ten steps: (1) research and information collecting (2) Planning (3) Develop preliminary form of product (4) Preliminary field testing (5) main product revision (6) main field testing to validate development product in large scale and compared with control product (7) operational product revision (8) operational field testing. It is validation test towards operational product that produced (9) Final product revision (10) dissemination and implementation product.

Respondent in this research is class 5 elementary school students in Surakarta. In the trial of small scale, the product is tested to 10 students and 1 teacher. In the trial of middle scale, the product is tested to 25 students and 2 teachers. Then, in the trial of large scale, it is tested to six classes (control class and experiment class). Instruments that used in this development research are questionnaire, questions, validation sheet, assessment sheet between students and observation sheet. Data processing in this research is conducted using descriptive analysis, including: expediency analysis and analysis of learning test result data. The method of collecting data in this research is questionnaire technique to know the expediency product (assignment worksheet based android multimedia) from topic experts, language experts, learning experts, media experts, and also the teacher and students' respond, learning result assessment, psychomotor, and behavior. Test technique to assess cognitive learning result, and assessment technique inter students to psychomotor and behavior. Before tested, product is validated by 9 experts using Aiken formula.

\section{RESULT AND DISCUSSION \\ Research and Information Collecting}

Activities conducted on the needs analysis in the form of field studies by giving questionnaires to students and teachers to the needs of learning media, learning condition in the classroom, the availability of learning materials, interviews with students and teachers, and analysis of national examination results in the last three years and daily test results.

In this preliminary research, it is found that the learning result of natural science is not yet optimal, there are some topics that are difficult to be understood by the students, especially the topic that need analysis process to an image and cycle. Thus, teachers need natural science learning media 
that appeals to learners and facilitates the students' understanding in learning natural science.

\section{Planning}

In this stage, the researcher design learning media based android multimedia by utilizing augmented reality based on KTSP curriculum.

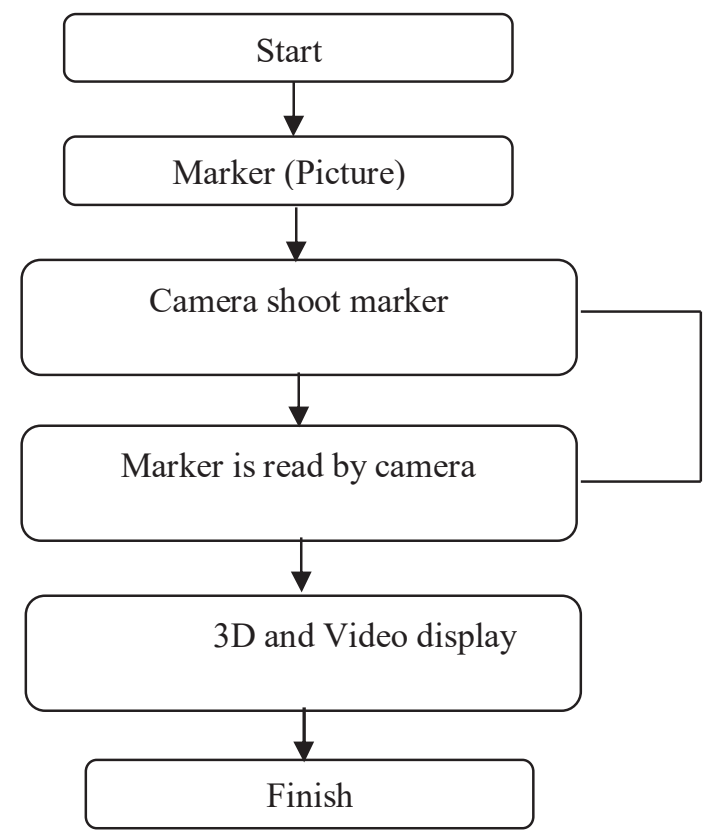

Picture 1. Augmented Reality Mechanism

\section{Develop Preliminary form of Product}

Researchers make learning media based on augmented reality technology based on the 5th grade of elementary school. The resulting product has been validated by 9 experts covering material experts, media experts, learning experts, linguists, and education practitioners. The results obtained that the media developed is valid with the acquisition of validation value Aiken 0.9528 .

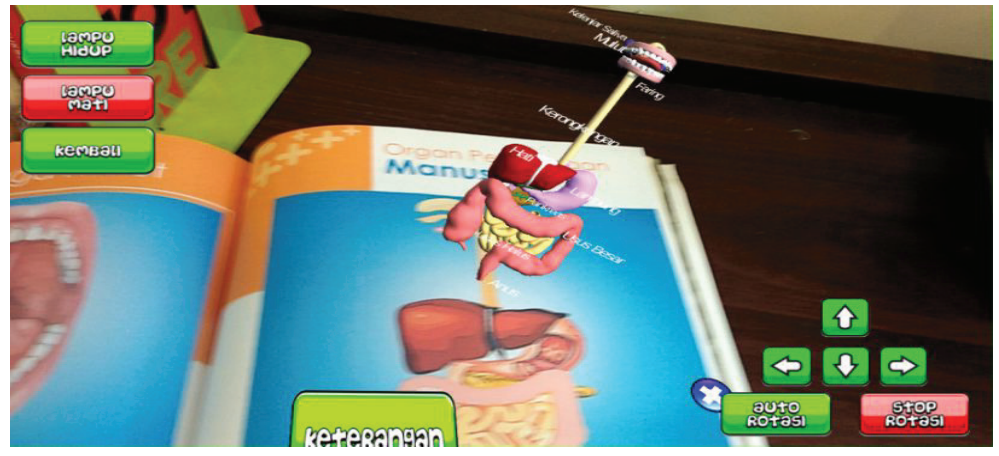


Picture 2. Display of Augmented Reality

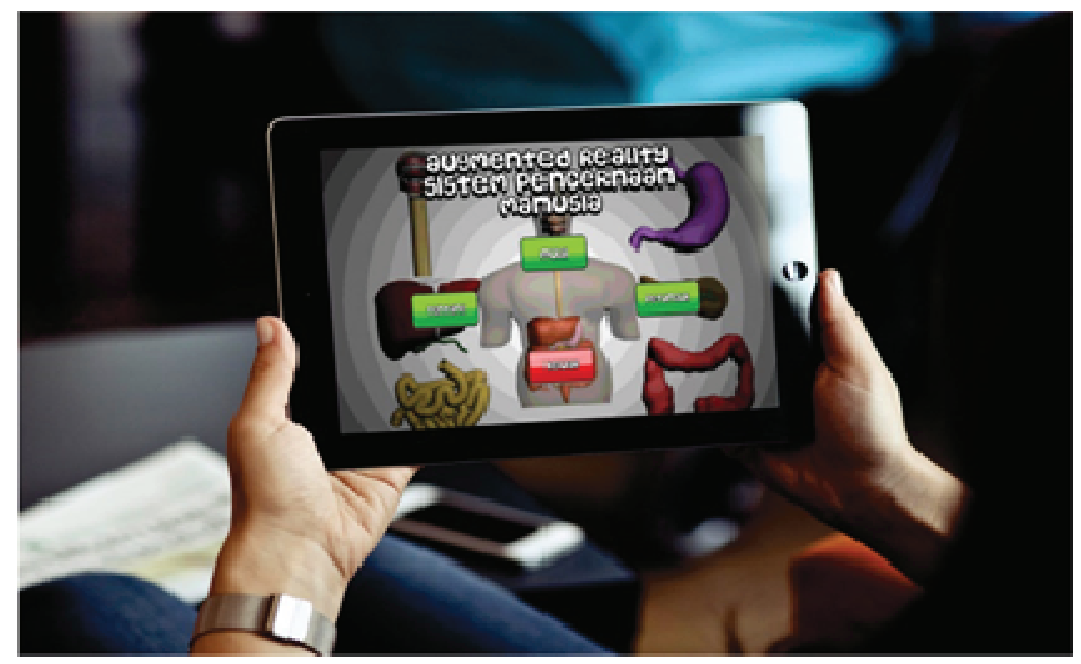

Gambar 2. Display of Application in android

\section{Preliminary Field Testing}

In preliminary field testing stage, product was tested to 10 students and 2 teachers. The aim of preliminary field-testing was to measure readability of product that was media. Furthermore, this test was conducted by distributing questioner to the students and teachers after they used the product. The result shows that the quality of developed media was average. The data analysis shows that students mean score in evaluating product is 83.96, and evaluation product from teacher is 81.25 .

Tabel 1. The Result of Preliminary Field Testing

\begin{tabular}{|c|c|c|c|c|c|}
\hline \multirow[t]{2}{*}{ No } & \multirow{2}{*}{$\begin{array}{l}\text { Evaluation } \\
\text { Aspect of } \\
\text { Quality }\end{array}$} & \multicolumn{2}{|l|}{ Students } & \multicolumn{2}{|l|}{ Teacher } \\
\hline & & $\begin{array}{l}\text { Persentage } \\
(\%)\end{array}$ & Category & $\begin{array}{l}\text { Persentage } \\
(\%)\end{array}$ & Category \\
\hline 1. & Content & 86,67 & Good & 83,33 & Average \\
\hline 2. & Language & 81,67 & Average & 83,33 & Average \\
\hline 3. & Display & 84,17 & Average & 79,16 & Average \\
\hline \multirow[t]{2}{*}{4.} & Abandonment & 83,33 & Average & 79.16 & Average \\
\hline & Mean & 83,96 & Average & 81,25 & Average \\
\hline
\end{tabular}




\section{Main Product Revision}

Main product revision was done to revise the product by considering on the result of preliminary field-testing. Revision was conducted from students' evaluation and teachers' evaluation toward the product. The revision includes improving the quality of sensitivity marker in augmented reality and others inappropriate terms.

\section{Main Field Testing}

In this stage, product was tested into larger scale. Developed media was tested into one class with the total number of students was 25 students and 2 teachers. The result shows that the quality of media is good. Students' evaluation score was 85.8 and teachers' evaluation score was 89.6.

Tabel 2. The Result of Main Field Testing

\begin{tabular}{|c|c|c|c|c|c|}
\hline \multirow[t]{2}{*}{ No } & \multirow{2}{*}{$\begin{array}{l}\text { Evaluation } \\
\text { Aspect of } \\
\text { Quality }\end{array}$} & \multicolumn{2}{|l|}{ Students } & \multicolumn{2}{|c|}{ Teacher } \\
\hline & & $\begin{array}{l}\text { Persentage } \\
(\%)\end{array}$ & Category & & $\begin{array}{l}\text { Persentage } \\
(\%)\end{array}$ \\
\hline 1. & Content & 86,74 & Good & 91,67 & Good \\
\hline 2. & Language & 89,77 & Good & 91,67 & Good \\
\hline 3. & Display & 88,26 & Good & 91.67 & Good \\
\hline \multirow[t]{2}{*}{4.} & Abandonment & 87,5 & Good & 95,83 & Good \\
\hline & Mean & 88,07 & Good & 92,71 & Good \\
\hline
\end{tabular}

\section{Operational Product Revision}

The quality revision and improvement of the product was done based on the result of main field-testing. In this stage, the quality revision and improvement was conducted by adding the explanation voice on augmented reality display.

\section{Operational Field Testing}

Operational field testing of developed media was conducted in 3 sample schools. The result of implementing the developed media in learning process shows the optimal result. It can be showed from the improvement of students learning outcome in some aspects such as cognitive, affective, and psychomotor. The following tables show the improvement score of students' learning outcome on. 


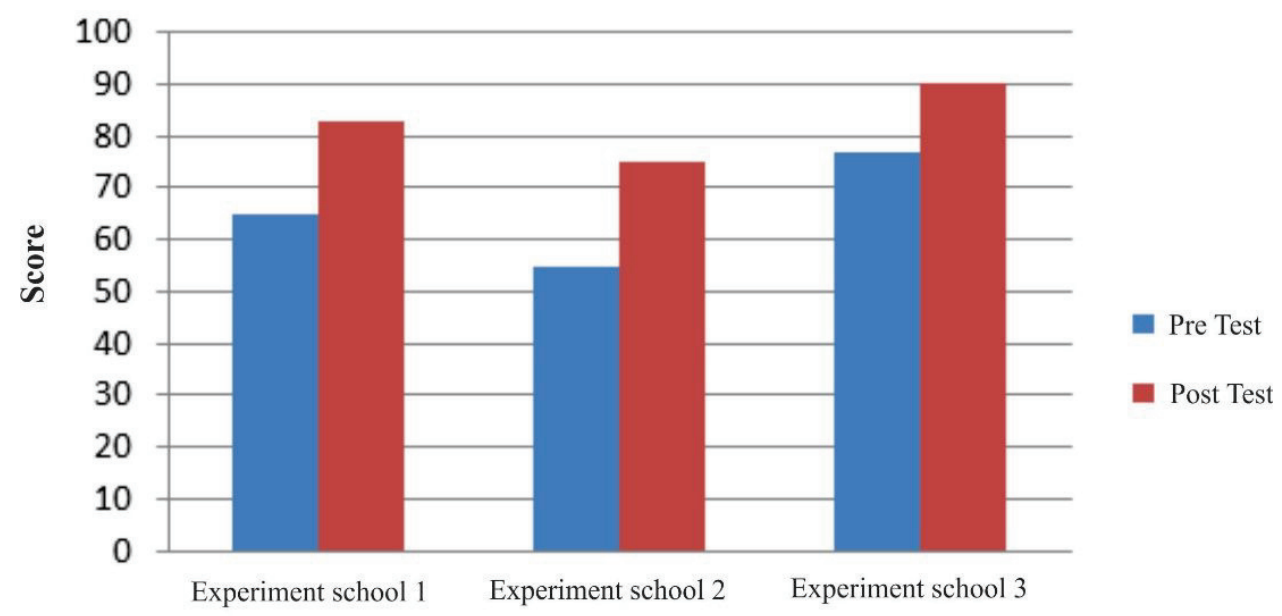

Object

Graphic 1. Mean Score of students' Cognitive Score

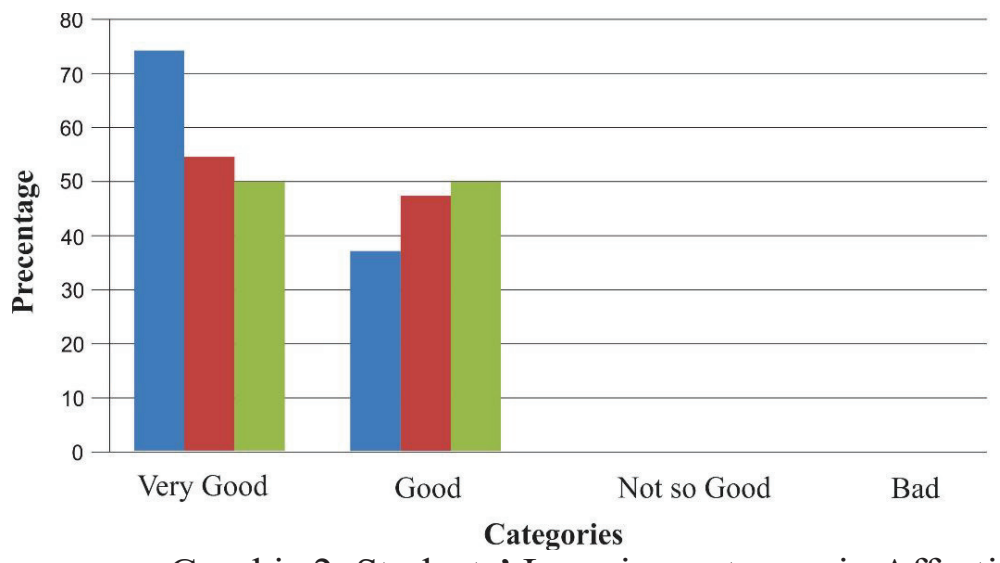

Experiment school 1

Experiment school 2

Experiment school 3

Graphic 2. Students' Learning outcome in Affective Aspect

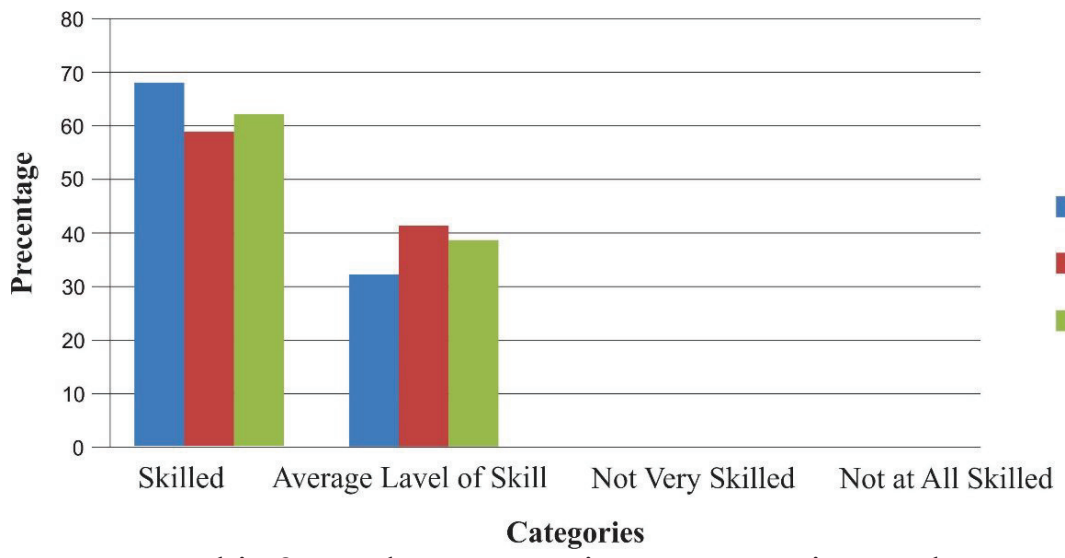

Experiment school 1

Experiment school 2

Experiment school 3

Graphic 3. Students' Learning Outcome in Psychomotor Aspect 


\section{Final Product Revision}

final product revision was conducted based on the result of operational field testing that shows that the quality of product is appropriate and relevant to be implemented and disseminated.

\section{Dissemination and Implementation}

After validation, testing and revision leaning media of science using augmented reality is appropriate and relevant to be implemented in learning process. The next stage is disseminating and implementing product. Furthermore, the developed product is presented in learning innovation forum and distributed to schools in Surakarta. Later on, play store is used to enlarge the distribution of produce and easy teachers and students to access and download the product.

\section{Conclusion}

In this research, researcher developed learning science media by using augmented reality technology. The product was validated by 9 experts including media expert, learning expert, language axpert and education practitioners. The result of validation shows that the developed media score was 0.9528 . The result of students' evaluation and teachers' evaluation toward the product was $88.07 \%$ and $92.71 \%$. It means that the developed product is good and relevant to be implemented in learning process. Moreover, the result of field testing also shows significant result. The result of field-testing shows that the developed media can improve students learning outcome on science viewed from cognitive aspect, affective aspect and psychomotor aspect. In the last stage of this development research, researcher disseminates the product to the elementary school teachers in Surakarta, distributes and provides download facility of product in playstore.

\section{References}

Arikunto, Suharsimi. (2013). Prosedur Penelitian Suatu Pendekatan Praktik. Jakarta : Rineka Cipta.

Chiang, T. H. C., Yang, S. J. H., \& Hwang, G. J. (2014). Students' online interactive patterns inaugmented reality-based inquiry activities. Journal Computers \& Education, 78, 97-108.

Dimyati \& Mujiono. (2006). Belajar dan Pembelajaran. Jakarta: Rineka Cipta.

Depdiknas. (2008). Kurikulum Tingkat Satuan Pendidikan. Jakarta: Dikmenum. Depdiknas.

Education For All Global Monitoring Report. (2011). Diperoleh 10 April 2016 
Journal Plus Education, ISSN: 1842-077X, E-ISSN (online) 2068-1151 Vol XIX (2018), No. 1. pp. $92-102$

http://www.Unesco.org/new/fileadmin/MULTIMEDIA/HQ/ED/pdf/gmr20 11-efa-development-index.pdf

Elango, P. (2013). Sistem Pemulihan Lembaran Kerja Bagi Nombor Negatif Berasaskan Realiti Luasan (AR2WN2). (Phd), Universiti Kebangsaan Malaysia, Bangi.

Gall, M.D., Gall, J.P. \& Borg, W.R. (2003). Educational Research an Introduction 7 th Ed. Boston: Pearson Education, Inc.

Hamalik, Oemar. (2009). Proses Belajar Mengajar. Bandung: Bumu Aksara. Harapan, Nazarudin Syafaat. (2012). Pemograman Aplikasi Mobile Smartphone dan Tablet PC Berbasis Android. Bandung: Informatika.

Harlen, W. (2006). Purpose and procedures for assesing science process skill. ProQuest. Assesment in education, 6 (1), pp 129-144.

Harre, Rom. (2002). Cognitive science: A philosophical introduction. London: SAGE Publications.

Irham, M. dan Wiyani, N. A. (2013). Psikologi Pendidikan: Teori dan Aplikasi dalam Proses Pembelajaran. Yogyakarta: Ar-ruzz Media.

Isjoni. (2013). Cooperative Learning. Bandung: Alfabeta.

Isnaningsih \& D. S. Bimo. (2013). Penerapan Lembar Kegiatan Siswa (LKS) Discovery berorientasi Keterampilan Proses Sains untuk Meningkatkan Hasil Belajar IPA. Jurnal Pendidikan IPA Indonesia, 2 (2), 136-141.

Kucuk, S., Yilmaz, R. M., \& Goktas, Y. (2014). Augmented Reality for Learning English: Achievement, Attitude and Cognitive Load Levels of Students. Journal Egitim Ve Bilim-Education and Science, 39 (176).

Majid, Abdul. (2007). Perencanaan Pembelajaran. Bandung: Remaja Rosdakarya.

Nazarudin. (2007). Manajemen Pembelajaran. Yogyakarta: Teras.

Programe for International Student Assessment (PISA). (2009). PISA 2009 Plus Result Performance of 15-years-old in reading, mathematics and science for 10 additional participants. Diperoleh 10 April 2016 dari http://nces.ed.gov/survey/pisa.

Belawati, Tian, dkk. (2003). Pengembangan Bahan Ajar. Jakarta : Universitas Terbuka.

Leach, J., Driver, R., Millar, R., \& Scott, P. (1997). A study of progression in learning about 'the nature of science': Issues of conceptualisation and methodology. International Journal of Science Education, 19(2), 147-166.

National Research Council. (2012). A framework for K-12 science education: Practices, crosscutting concepts, and core ideas. Washington, DC: The National Academies Press.

Stiggins, R. J. (2005). Student-involved assessment for learning (4th ed.). Upper Saddle River, NJ: Pearson Prentice Hall. Stiggins, R. J., \& Conklin, N. F. (1992). In teachers' hands: Investigating the practices of classroom assessment. Albany, NY: State University of New York Press. 
Journal Plus Education, ISSN: 1842-077X, E-ISSN (online) 2068-1151 Vol XIX (2018), No. 1. pp. $92-102$

Sagala, Syaiful. (2010). Konsep dan Makna Pembelajaran. Bandung: Alfabeta.

Sanjaya, Wina. (2013). Penelitian Pendidikan, Jenis, Metode dan Prosedur Pendidikan. Jakarta: Kencana Prenada.

Sri Sulistyorini. (2007). Model Pembelajaran IPA Sekolah Dasar dan Penerapannya dalam KTSP. Yogyakarta: Tiara Wacana.

Sudarwan Danim. (1995). Media Komunikasi Pendidikan. Jakarta: Bumi Aksara.

Sudjana, Nana. (2004). Dasar-Dasar Proses Belajar Mengajar. Bandung: Sinar Baru Algensindo.

Sugiyono. (2015). Metode Penelitian Pendidikan Pendekatan Kuantitatif, Kualitatif, dan R\&D. Bandung: Alfabeta. (2015). Metode Penelitian \& Pengembangan Research and Development. Bandung: Alfabeta

Susanto, Ahmad. (2013). Teori Belajar dan Pembelajaran di Sekolah Dasar. Jakarta: Kencana Prenada Media Grup.

Samatowa, Utsman. (2006). Bagaimana Membelajarkan IPA di Sekolah Dasar. Jakarta: Depdiknas.

Majid, Ambul. (2013). Strategi Pembelajaran. Bandung: Remaja Rosdakarya.

Mulyasa. (2010). Kurikulum Tingkat Satuan Pendidik (KTSP). Bandung: PT. Remaja Rosdakarya.

Nurina, Irma. (2015). Penerapan Lembar Kerja Siswa berbasis Penugasan Terbimbing untuk Meningkatkan Motivasi dan Minat Belajar Siswa di Sekolah Dasar. (Tesis). Universitas Negeri Semarang, Semarang.

Treagust, D. F. \& Duit, R. (2008). Conceptual change: a discussion of theoretical, methodological and practical challenges for science education. Cultural Studies of Science Education, 3, 297-328. 